Vol. 2 No. 1 Maret 2021

e-ISSN : 2721-4109

REKAN

Riset Elonomi. Akuntansi dan

DOI: $10.30812 /$ rekan.v2i1.1120

\title{
Analisis Pengaruh Persepsi Harga, Kualitas Produk dan Citra Merek Terhadap Keputusan Pembelian
}

(Studi Pada Konsumen Sari Roti di Kota Semarang)

\author{
Agus Budi Purwanto, Hendro Budhi Risaputro \\ Manajemen STIE Pelita Nusantara Semarang \\ agusbudipurwanto02@gmail.com
}

\begin{abstract}
Abstrak
Tujuan dalam penelitian ini adalah menganalisis pengaruh Persepsi Harga, Kualitas Produk dan Citra Merek terhadap Keputusan Pembelian pada konsumen Sari Roti di Kelurahan Wonodri Semarang. Populasi dalam penelitian ini adalah seluruh konsumen yang membeli Sari Roti di Indomart Kota Semarang. Sampel yang diambil sejumlah 130 orang. Teknik sampling yang digunakan stratified proportional sampling. Alat analisis data yang digunakan dalam penelitian ini adalah analisis regresi berganda. Berdasarkan hasil penelitian : Terdapat pengaruh yang positif dan signifikan antara Persepsi Harga terhadap Keputusan Pembelian, Terdapat pengaruh yang positif dan signifikan antara Kualitas Produk terhadap Keputusan Pembelian, Terdapat pengaruh yang positif dan signifikan antara Citra Merek terhadap Keputusan Pembelian, Secara simultan terdapat pengaruh yang positif dan signifikan antara Persepsi Harga, Kualitas Produk dan Citra Merek terhadap Keputusan Pembelian.
\end{abstract}

Kata Kunci : Persepsi Harga, Kualitas Produk, Citra Merek, Keputusan Pembelian

\begin{abstract}
The purpose of this study was to analyze the influence of Price Perception, Product Quality and Brand Image on Purchasing Decisions on Sari Roti consumers in Wonodri Village Semarang. The population in this study were all consumers who bought Sari Roti in Indomart. The sample is 130 people. The sampling technique used is stratified proportional sampling. The data analysis tool used in this study is multiple regression analysis. Based on the results of the study: There is a positive and significant influence between Price Perception on Purchasing Decisions, There is a positive and significant influence between Product Quality on Purchasing Decisions, There is a positive and significant influence between Brand Image on Purchasing Decisions, Simultaneously there is a positive and significant effect between Price Perception, Product Quality and Brand Image on Purchasing Decisions.
\end{abstract}

Keywords: Price Perception, Product Quality, Brand Image, Purchasing Decision 


\section{Pendahuluan}

Bidang usaha yang saat ini berkembang pesat adalah produk makanan roti. Pasar bisnis makanan roti di Indonesia memiliki potensi yang besar, karena walaupun roti bukan makanan pokok, permintaan akan roti terus meningkat yaitu berkisar 10\%-15\% per tahun (Rahmawaty, 2014). Seiring dengan berkembangnya industri roti di Indonesia, kompetisi di pasar ini pun semakin ketat. Ketatnya persaingan bisnis roti ini dapat dilihat dari beberapa pemain bisnis roti antara lain roti dengan merek Sari Roti, Lauw, Sharon, BreadTalk, Holland Bakery,dan masih banyak lagi.

Sari Roti diproduksi PT. Nippon Indosari Corpindo Tbk (NIC) dan memiliki pabrik di Semarang dan kantor distribusi produk sari roti di Jawa Tengah. PT. Nippon Indosari Corpindo Tbk (NIC) dalam segi persaingan produk bakery, di kota Semarang memiliki persaingan yang sangat ketat sebanyak 18 merk roti dengan display toko 2 merk roti tanpa display toko. Sari Roti memiliki keunikan dengan system penjualan produk tanpa memiliki display toko seperti pesaing. Merek Sari Roti juga selalu menempati posisi tertinggi dalam survey Top Brand kategori Roti Tawar yang dilakukan oleh lembaga konsultasi Frontier (www.topbrandaward. com, 2019) dari tahun 2016 fase 2 sampai tahun 2019 fase 2.

Tabel 1 : Top Brand Index Roti Tawar

\begin{tabular}{|l|c|c|c|c|}
\hline \multirow{2}{*}{\multicolumn{1}{|c|}{ Merk }} & \multicolumn{4}{|c|}{ Tahun } \\
\cline { 2 - 5 } & 2016 & 2017 & 2018 & 2019 \\
\hline Sari Roti & $72,9 \%$ & $69,1 \%$ & $72,8 \%$ & $58,0 \%$ \\
\hline Lauw & $2,1 \%$ & $1,3 \%$ & $1,5 \%$ & $2,3 \%$ \\
\hline BreadTalk & $1,8 \%$ & $1,5 \%$ & $6,5 \%$ & $9,5 \%$ \\
\hline Holand Bakery & $1,5 \%$ & $1,2 \%$ & $4,4 \%$ & $1,9 \%$ \\
\hline
\end{tabular}

Sumber: http://topbrand_award.com, 2019

Suatu merek yang dirancang perusahaan harus dapat memenuhi apa yang dibutuhkan dan diinginkan konsumen serta dikomunikasikan dengan baik, sehingga pada saat konsumen membutuhkan produk tertentu, maka konsumen akan memutuskan produk dengan merek tersebut yang menjadi pilihan utama untuk dibeli. Menurut Kotler (2016:227), Keputusan Pembelian adalah tindakan dari konsumen untuk mau membeli atau tidak terhadap produk. Kotler dan Keller (2016:179-184) menyatakan bahwa faktor-faktor utama yang memengaruhi perilaku pembelian konsumen adalah faktor kebudayaan, faktor sosial, faktor personal dan faktor psikologi. Selain empat faktor tersebut, perilaku konsumen juga dapat dipengaruhi dari stimuli pemasaran berupa bauran pemasaran yang meliputi produk, harga, promosi dan distribusi (Kotler, 2016;34).

Berkaitan dengan obyek penelitian, roti dengan merk Sari Roti diproduksi memproduksi roti secara bersih dan sehat, selain itu perusahaan ini mampu menjaga kualitas dari produk yang mereka jual. Berikut ini merupakan data penjualan yang diperoleh produk Sari Roti dalam kurun waktu 2014 hingga 2018. 
Vol. 2 No. 1 Maret 2021

e-ISSN : 2721-4109

REKAN

Riset Eloonomi, Akuntansi dan

DOI: $10.30812 /$ rekan.v2i1.1120

Grafik 1

Data Volume Penjualan Sari Roti Nasional Tahun 2014-2018

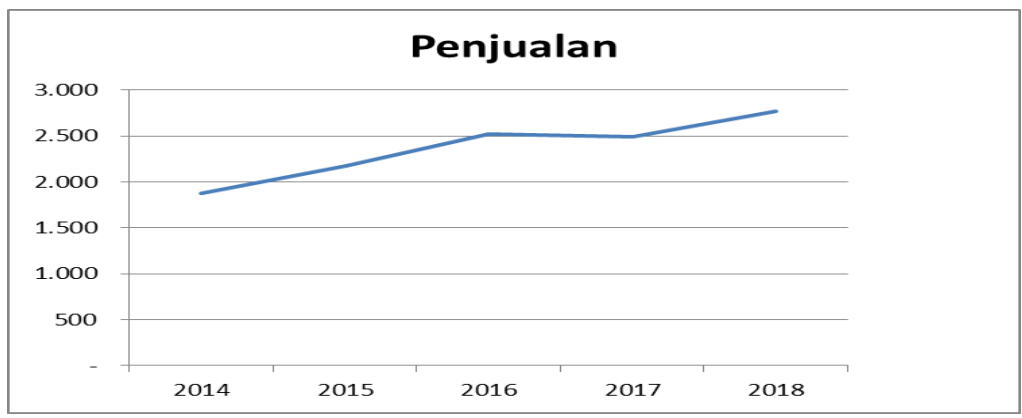

Sumber: www.idx.co.id

Data diatas menunjukkan volume penjualan Sari Roti dari tahun 2014 sampai 2018 menunjukan kenaikan dan penurunan. Penurunan penjualan pada tahun 2017 menunjukkan rendahnya keputusan pembelian yang dilakukan oleh konsumen, hal ini dikarenakan bertambahnya jumlah produsen roti maka bertambah pula jumlah pesaing dalam industri roti tersebut sehingga kondisi ini berimplikasi terhadap tingkat persaingan yang juga semakin tinggi untuk merebut pangsa pasar.

Berdasarkan permasalahan di atas, penelitian ini bertujuan untuk menganalisis pengaruh Persepsi Harga, Kualitas Produk dan Citra Merek terhadap Keputusan Pembelian pada konsumen Sari Roti di Kelurahan Wonodri Semarang.

\section{Kerangka Pemikiran Teoritis Dan Perumusan Hipotesis Kerangka Berfikir}

Penelitian ini bertujuan untuk menganalisis pengaruh harga, Kualitas Produk dan Citra Merek terhadap Keputusan Pembelian yang dikembangkan dalam model ini adalah sebagai berikut:

\section{Gambar 1 Kerangka Pemikiran}

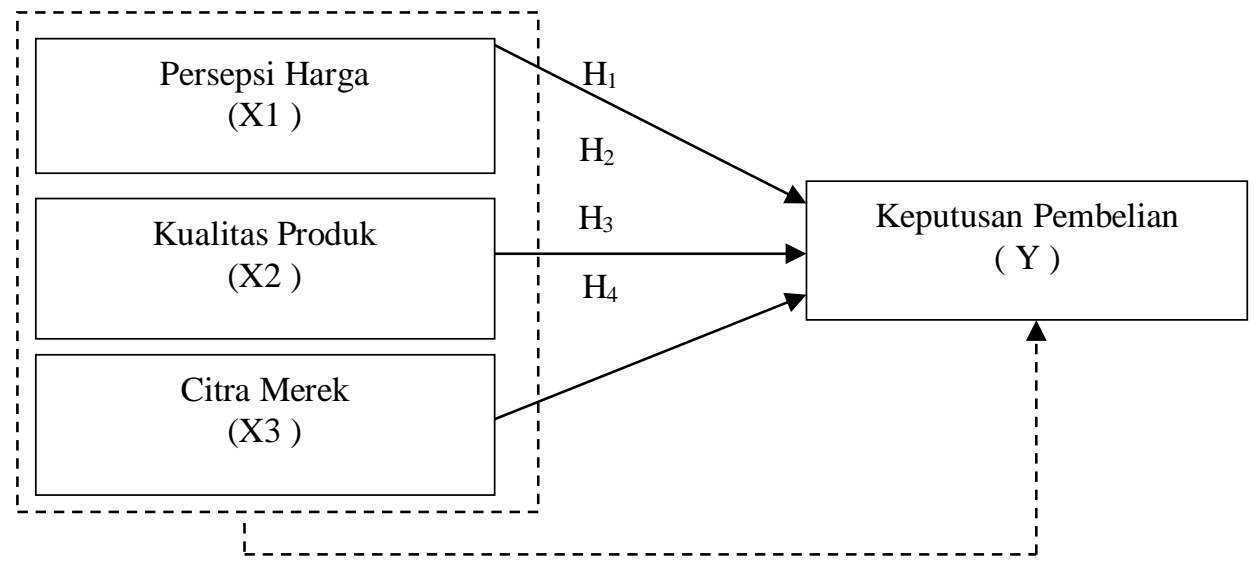

\section{Hipotesis Penelitian}

$\mathrm{H}_{1}$ : Terdapat pengaruh Persepsi harga terhadap Keputusan Pembelian pada konsumen Sari Roti di Kelurahan Wonodri Semarang

$\mathrm{H}_{2}$ : Terdapat pengaruh Kualitas Produk terhadap Keputusan Pembelian pada konsumen Sari Roti di Kelurahan Wonodri Semarang 
$\mathrm{H}_{3}$ : Terdapat pengaruh Citra Merek terhadap Keputusan Pembelian pada konsumen Sari Roti di Kelurahan Wonodri Semarang

$\mathrm{H}_{4}$ : Terdapat pengaruh Persepsi Harga, Kualitas Produk dan Citra Merek secara bersama-sama terhadap Keputusan Pembelian pada konsumen Sari Roti di Kelurahan Wonodri Semarang

\section{Metode Penelitian Desain}

\section{Penelitian}

Penelitian yang digunakan adalah penelitian Kausal Komparatif. Penelitian ini bertujuan untuk menyelidiki kemungkinan sebab akibat dengan cara : berdasarkan pengamatan terhadap akibat yang ada mencari kembali faktor yang menjadi penyebab melalui data tertentu.

Variabel yang digunakan dalam penelitian ini terdapat 3 (tiga) variabel independen dan 1 (satu) variabel dependen. Variabel bebas (independen) adalah variabel yang mempengaruhi atau yang menjadi sebab perubahannya atau timbulnya variabel dependen atau terikat (Sugiyono, 2016). Variabel independen dalam penelitian ini adalah: Persepsi Harga $\left(\mathrm{X}_{1}\right)$, Kualitas Produk $\left(\mathrm{X}_{2}\right)$, dan Citra Merek $\left(\mathrm{X}_{3}\right)$. Variabel terikat (dependen) adalah variabel yang dipengaruhi atau yang menjadi akibat karena adanya variabel bebas (Sugiyono, 2016). Variabel dependen dalam penelitian ini adalah: Keputusan Pembelian (Y). Definisi operasional pada variabel-variabel dalam penelitian ini adalah:

\section{Tabel 2 : Definisi Operasional}

\begin{tabular}{|c|c|c|}
\hline Variabel & Definisi & Indikator \\
\hline $\begin{array}{l}\text { Persepsi Harga } \\
\text { (X1) }\end{array}$ & $\begin{array}{l}\text { Persepsi harga merupakan } \\
\text { bagaimana informasi harga } \\
\text { dipahami oleh konsumen dan } \\
\text { dibuat bermakna bagi } \\
\text { mereka (Peter dan Olson, } \\
\text { 2016). }\end{array}$ & $\begin{array}{l}\text { 1. Harga produk terjangkau } \\
\text { 2. Harga produk kompetitif } \\
\text { dengan produk merek lain } \\
\text { 3. Kesesuaian harga dengan } \\
\text { Kualitas Produk } \\
\text { 4. Kesesuaian harga dengan } \\
\text { manfaat } \\
\text { Khakim (2015), Sari (2018) }\end{array}$ \\
\hline $\begin{array}{c}\text { Kualitas Produk } \\
\text { (X2) }\end{array}$ & $\begin{array}{l}\text { Kualitas Produk adalah } \\
\text { karakteristik produk atau jasa } \\
\text { yang bergantung pada } \\
\text { kemampuannya } r \text { untuk } \\
\text { memuaskan kebutuhan } \\
\text { pelanggan yang dinyatakan } \\
\text { atau diimplikasikan (Kotler } \\
\text { \& Armstrong, 2016:283). }\end{array}$ & $\begin{array}{l}\text { 1. Kemasan tidak pudar dan } \\
\text { terbaca } \\
\text { 2. Customization (Keberagaman) } \\
\text { 3. Durability (Ketahanan) } \\
\text { 4. Reliability (Kehandalan) } \\
\text { Khakim (2015), Sari (2018) }\end{array}$ \\
\hline $\begin{array}{l}\text { Citra Merek } \\
\text { (X3) }\end{array}$ & \begin{tabular}{lrr} 
Citra Merek & merupakan \\
deskripsi & asosiasi dan \\
keyakinan & \multicolumn{2}{c}{ konsumen } \\
terhadap & merek & tertentu \\
(Tjiptono, 2016) &
\end{tabular} & $\begin{array}{l}\text { 1. Merek terkenal } \\
\text { 2. Merek yang bergengsi } \\
\text { 3. Mudah diingat } \\
\text { 4. Reputasi yang baik } \\
\text { Khakim (2015), Rangkuti } \\
(2016: 44)\end{array}$ \\
\hline
\end{tabular}


Vol. 2 No. 1 Maret 2021

REKAN

Riset Ekonomi. Aleuntansi dan

e-ISSN : 2721-4109

DOI: $10.30812 /$ rekan.v2i1.1120

\begin{tabular}{|c|l|l|}
\hline $\begin{array}{c}\text { Keputusan } \\
\text { pembelian } \\
(\mathrm{Y})\end{array}$ & Keputusan pembelian & 1.Kemantapan membeli \\
& merupakan keputusan & 2.Pertimbangan dalam membeli \\
& konsumen mengenai & 3.Kesesuaian atribut dengan \\
& preferensi atas merek-merek & keinginan dan kebutuhan. \\
& yang ada di dalam kumpulan & 4.Rekomendasi kepada orang lain \\
& pilihan (Kotler dan Keler, & /keluarga \\
& Khakim (2015), Kotler (2016) \\
\hline
\end{tabular}

\section{Populasi dan Teknik Sampling \\ Populasi}

Arikunto (2016) berpendapat bahwa populasi adalah keseluruhan subyek penelitian. Populasi dalam penelitian ini adalah seluruh konsumen yang membeli Sari Roti di Indomart Semarang dengan sampel di Indomaret Wonodri Krajan, Indomaret Wonodri Sendang dan Indomaret Singosari.

\section{Teknik Sampling}

Teknik sampling yang digunakan stratified proportional sampling artinya, pengambilan sampel terlebih dahulu dikelompokkan dalam beberapa sub populasi sehingga tiap sub-populasi yang ada memiliki anggota sampelnya (Umar, 2015). Sampel tiap-tiap bagian dapat dilihat pada tabel 3.2:

\section{Tabel 3}

\section{Besarnya Sampel Setiap Bagian}

\begin{tabular}{|c|c|c|c|}
\hline \multicolumn{1}{|c|}{ Keterangan } & Jumlah & Proporsi & \multicolumn{1}{c|}{ Sampel } \\
\hline Indomaret Wonodri Krajan & 60 & $60 / 190=0,316$ & $0,316 \times 130=41$ \\
\hline Indomaret Wonodri Sendang & 50 & $50 / 190=0,263$ & $0,263 \times 130=34$ \\
\hline Indomaret Singosari & 80 & $80 / 190=0,421$ & $0,421 \times 130=55$ \\
\hline \multicolumn{1}{|c|}{ Jumlah } & 190 & 1,000 & 130 \\
\hline
\end{tabular}

Sumber : Data Primer yang diolah, 2020

\section{Instrumen Penelitian}

Kuesioner adalah suatu metode dimana peneliti menyusun daftar pertanyaan secara tertulis yang kemudian dibagikan kepada responden dalam hal ini konsumen membeli Sari Roti di Indomart di Semarang yaitu Indomaret Wonodri Krajan, Indomaret Wonodri Sendang dan Indomaret Singosari guna memperoleh data yang berhubungan dengan kegiatan penelitian yaitu Persepsi Harga, Kualitas Produk, Citra Merek dan Keputusan Pembelian. Kuesioner mulai disebar pada konsumen mulai bulan Juni 2020. Selain menggunakan instrumen tersebut juga dilakukan wawancara secara langsung yaitu memperoleh sejumlah data melalui tanya jawab sambil bertatap muka untuk mendapatkan data yang diperlukan Pengolahan data kuesioner dalam penelitian ini dilakukan tahapan-tahapan sebagai berikut: 
Vol. 2 No. 1 Maret 2021

REKAN

Riset Ekonomi, Akuntansi dan

e-ISSN : 2721-4109

DOI: $10.30812 /$ rekan.v2i1.1120

1. Editing yaitu proses yang dilakukan setelah data terkumpul untuk melihat apakah jawaban pada kuesioner telah terisi dengan lengkap atau belum

2. Coding yaitu proses pemberian kode tertentu terhadap macam jawaban dari kuesioner untuk dikelompokkan ke dalam katagori yang sama.

3. Pemberian score atau nilai Pemberian score atau penilaian ini digunakan skala Likert yang merupakan salah satu cara untuk menentukan score. Kriteria penilaian ini digolongkan dalam 5 tingkatan dengan penilaian sebagai berikut:
a. Untuk jawaban sangat setuju, diberi nilai 5
b. Untuk jawaban setuju, diberi nilai 4
c. Untuk jawaban netral, diberi nilai 3
d. Untuk jawaban tidak setuju, diberi nilai 2
e. Untuk jawaban sangat tidak setuju, diberi nilai 1

4. Tabulasi yaitu pengelompokkan tes jawaban dengan teliti yang terarah kemudian dihitung dan dijumlah sampai terwujud kedalam bentuk tabel.

\section{Metode Analisis Data}

Dalam melakukan penelitian ini dilakukan analisis data dengan cara Analisis Kuantitatif. Dalam penelitian analisis data kuantitatif digunakan untuk mengolah data yang diperoleh dari jawaban kuesioner kemudian diolah dan dilakukan pengujian hipotesa dengan menggunakan bantuan SPSS. Alat analisis yang digunakan adalah Analisis Regresi Linier Berganda, uji t dan uji F. Analisis ini digunakan untuk mencari persamaan regresi dari pengaruh antara Persepsi Harga $\left(\mathrm{X}_{1}\right)$, Kualitas Produk $\left(\mathrm{X}_{2}\right)$, dan Citra Merek $\left(\mathrm{X}_{3}\right)$ terhadap Keputusan Pembelian $(\mathrm{Y})$.

\section{Hasil Dan Pembahasan}

\section{Pengkajian Hipotesis}

Untuk menguji pengaruh Persepsi Harga, Kualitas Produk dan Citra Merek terhadap Keputusan Pembelian menggunakan analisis stasistik yaitu model analisis regresi berganda seperti pada tabel berikut ini

\section{Tabel 4 : Hasil Analisis Regresi}

Coefficients $^{\text {a }}$

\begin{tabular}{|c|c|c|c|c|c|}
\hline \multirow[b]{2}{*}{ Model } & \multicolumn{2}{|c|}{$\begin{array}{c}\text { Unstandardized } \\
\text { Coefficients }\end{array}$} & \multirow{2}{*}{$\begin{array}{c}\begin{array}{c}\text { Standardized } \\
\text { Coefficients }\end{array} \\
\text { Beta }\end{array}$} & \multirow[b]{2}{*}{$\mathrm{T}$} & \multirow[b]{2}{*}{ Sig. } \\
\hline & B & Std. Error & & & \\
\hline 1 (Constant) & 3,060 &, 882 & & 3,468 & ,001 \\
\hline Persepsi Harga & ,241 & ,074 & ,260 & 3,267 & ,001 \\
\hline Kualitas Produk &, 327 & ,077 &, 367 & 4,262 & ,000 \\
\hline Citra Merek & ,224 & ,071 & ,246 & 3,176 &, 002 \\
\hline
\end{tabular}

a. Dependent Variable: Keputusan Pembelian

Berdasarkan Tabel 9 di atas dapat dijelaskan persamaan regresi linier berganda sebagai berikut : $\mathrm{Y}=3,060+0,241 \mathrm{X}_{1}+0,327 \mathrm{X}_{2}+0,224 \mathrm{X}_{3}$ 
Dari persamaan regresi berganda tersebut dapat dijelaskan bahwa Persepsi Harga $\left(\mathrm{X}_{1}\right)$, Kualitas Produk $\left(\mathrm{X}_{2}\right)$ dan Citra Merek $\left(\mathrm{X}_{3}\right)$ berpengaruh positif terhadap Keputusan Pembelian Analisis pengujian hipotesis dengan Uji $\mathrm{t}$ :

1. Pengujian hipotesis Persepsi Harga terhadap Keputusan Pembelian

Dari hasil perhitungan t-hitung lebih besar dari t-tabel yaitu sebesar 3,267 > 1,979 atau sign $(0,001) \leq 0,05$ dengan demikian H1 diterima. Maka dapat disimpulkan ada pengaruh Persepsi Harga terhadap Keputusan Pembelian.

2. Pengujian hipotesis Kualitas Produk terhadap Keputusan Pembelian

Dari hasil perhitungan t-hitung lebih besar dari t-tabel yaitu sebesar 4,262 > 1,979 atau sign $(0,000) \leq 0,05$ dengan demikian H2 diterima. Maka dapat disimpulkan ada pengaruh Kualitas Produk terhadap Keputusan Pembelian.

3. Pengujian hipotesis Citra Merek terhadap Keputusan Pembelian

Dari hasil perhitungan t-hitung lebih besar dari t-tabel yaitu sebesar 3,176>1,979 atau sign $(0,002) \leq 0,05$ dengan demikian H3 diterima. Maka dapat disimpulkan ada pengaruh Citra Merek terhadap Keputusan Pembelian.

Analisis pengujian hipotesis dengan Uji F :

\section{Tabel 5 : Hasil Uji F} ANOVA ${ }^{a}$

\begin{tabular}{|c|c|c|c|c|c|}
\hline Model & $\begin{array}{l}\text { Sum of } \\
\text { Squares }\end{array}$ & $\mathrm{df}$ & Mean Square & $\mathrm{F}$ & Sig. \\
\hline $\begin{array}{ll}1 & \text { Regressio } \\
\mathrm{n}\end{array}$ & 462,148 & 3 & 154,049 & $\begin{array}{r}56,96 \\
4\end{array}$ &, $000^{\mathrm{b}}$ \\
\hline Residual & 340,744 & 126 & 2,704 & & \\
\hline Total & 802,892 & 129 & & & \\
\hline
\end{tabular}

a. Dependent Variable: Keputusan Pembelian

b. Predictors: (Constant), Citra Merek, Persepsi Harga, Kualitas Produk

Berdasarkan Tabel 10 di atas dapat diketahui hasil perhitungan F-hitung $(56,964)>$ F-tabel $(2,677)$ atau sig $\mathrm{F}(0,000) \leq 0,05$ dengan demikian $\mathrm{H} 4$ diterima. Maka dapat disimpulkan ada pengaruh Persepsi Harga, Kualitas Produk dan Citra Merek secara bersama-sama terhadap Keputusan Pembelian.

Hasil pengujian koefisien determinasi :

Tabel 6 : Nilai Koefisien Determinasi Model Summary ${ }^{b}$

\begin{tabular}{|l|r|r|r|r|}
\hline Model & R & R Square & $\begin{array}{c}\text { Adjusted R } \\
\text { Square }\end{array}$ & $\begin{array}{c}\text { Std. Error of } \\
\text { the Estimate }\end{array}$ \\
\hline 1 &, $759^{\mathrm{a}}$ &, 576 &, 565 & 1,64448 \\
\hline
\end{tabular}

a. Predictors: (Constant), Citra Merek, Persepsi Harga, Kualitas

Produk

b. Dependent Variable: Keputusan Pembelian

Berdasarkan Tabel 11 di atas menunjukkan bahwa nilai Koefisien determinasi (Adjusted $R$ Square) adalah sebesar 0,565 yang berarti variasi perubahan Keputusan Pembelian dipengaruhi variasi variabel Persepsi Harga, Kualitas Produk dan Citra Merek sebesar 56,5\% dan sisanya 43,5\% dipengaruhi oleh faktor-faktor lain diluar penelitian misal lokasi, promosi. 
Vol. 2 No. 1 Maret 2021

\section{Pembahasan}

\section{Pengaruh Persepsi Harga Terhadap Keputusan Pembelian}

Dari hasil penelitian diketahui bahwa terdapat pengaruh signifikan antara Persepsi Harga terhadap Keputusan Pembelian, hal ini dapat diartikan bahwa semakin baik Persepsi Harga maka Keputusan Pembelian akan semakin tinggi. Persepsi atas harga menyangkut bagaimana informasi harga dipahami oleh konsumen dandibuat bermakna bagi mereka. Dalam pengolahan kognitif informasi harga, konsumen bias membandingkan antara harga yang dinyatakan dengan sebuah harga atau kisaran harga yang mereka bayangkan atas produk tersebut .harga yang ada dipikiran sebagai bahan melakukan perbandingan tersebut disebut harga acuan internal. Harga acuan internal adalah harga yang dianggap pantas oleh konsumen, harga yang telah ada secara historis atau yang dibayangkan konsumen sebagai harga pasar yang tinggi atau rendah (Peter \& Olson 2016). Konsumen biasanya tidak mengevaluasi harga pasti (exact price) dari suatu produk ketika hendak melakukan pembelian, namun mereka mempersepsikan harga produk tersebut sebagai suatu harga yang murah, masuk akal (reasonable), atau mahal berdasarkan internal reference price mereka (Peter \& Olson 2016). Harga memiliki peranan yang sangat penting dalam mempengaruhi keputusan konsumen dalam membeli produk, sehingga sangat menentukan keberhasilan pemasaran suatu produk.

\section{Pengaruh Kualitas Produk Terhadap Keputusan Pembelian}

Dari hasil penelitian diketahui bahwa terdapat pengaruh signifikan antara Kualitas Produk terhadap Keputusan Pembelian, hal ini dapat diartikan bahwa semakin meningkat Kualitas Produk maka Keputusan Pembelian akan semakin tinggi. Kualitas diukur melalui sudut pandang konsumen terhadap kualitas produk itu sendiri, sehingga selera konsumen disini juga sangat berpengaruh. Jadi dalam mengelola kualitas suatu produk harus sesuai dengan kegunaan yang diinginkan oleh konsumen. Kualitas produk merupakan kemampuan suatu produk untuk melakukan fungsinya. Kemampuan itu meliputi: daya tahan, kehandalan, ketelitian yang dihasilkan, kemudahan untuk dioperasikan dan diperbaiki, serta atribut yang berharga pada produk secara keseluruhan (Kotler dan Armstrong, 2016: 439). Pada dasarnya, konsumen membeli suatu produk bukan hanya sekedar ingin memiliki produk tersebut. Konsumen memutuskan untuk melakukan pembelian suatu produk karena produk tersebut memiliki kualitas yang sesuai dengan keinginan dan kebutuhannya.

\section{Pengaruh Citra Merek Terhadap Keputusan Pembelian}

Dari hasil penelitian diketahui bahwa terdapat pengaruh Citra Merek terhadap Keputusan Pembelian, hal ini diartikan bahwa pengaruh Citra Merek yang tinggi akan berpengaruh terhadap Keputusan Pembelian. Citra terhadap merek berhubungan dengan sikap yang berupa keyakinan dan preferensi terhadap suatu merek. Konsumen yang memiliki citra positif terhadap suatu merek, akan lebih memungkinkan untuk melakukan pembelian. Implikasi dari hal tersebut menjadikan merek suatu produk menciptakan image dari produk itu sendiri dari benak konsumen dan menjadikan motivasi dasar bagi konsumen dalam memilih suatu produk Citra merupakan keseluruhan persepsi terhadap produk atau merek yangdibentuk dari informasi dan pengalaman masa lalu terhadap produk atau merek itu (Sutisna, 2014). Konsumen dengan citra positif terhadap suatu produk, lebih memungkinkan untuk melakukan pembelian.

\section{Pengaruh Persepsi Harga, Kualitas Produk dan Citra Merek Terhadap Keputusan Pembelian}


Vol. 2 No. 1 Maret 2021

Dari hasil penelitian diketahui bahwa terdapat pengaruh Persepsi Harga, Kualitas Produk dan Citra Merek terhadap Keputusan Pembelian, hal ini dapat diartikan bahwa harga mempengaruhi keputusan konsumen dalam melakukan pembelian (Kotler dan Amstrong, 2016). Harga memiliki pengaruh yang besar terhadap konsumen untuk membeli. Setiap konsumen membutuhkan lebih banyak bentuk diskon atau potongan harga dan paket barang dengan harga yang murah. Konsumen juga sangat memperhatikan kualitas produk yang akan dibeli, apakah produk tersebut memiliki kualitas yang baik dan apabila dikonsumsi tidak berbahaya, ataupun menggunakan bahan-bahan yang mengandung bahan kimia atau tidak. Konsumen menginginkan kualitas produk yang terbaik dalam melakukan keputusan pembelian. Menurut Kotler (2016) kualitas produk (product quality) adalah ciri dan karakteristik suatu barang atau jasa yang berpengaruh pada kemampuannya untuk memuaskan kebutuhan yang dinyatakan atau tersirat. Kualitas mencerminkan semua dimensi penawaran produk yang menghasilkan manfaat bagi konsumen. Citra merek dapat memberikan keyakinan bagi konsumen dalam melakukan pembelian suatu produk. Citra merek itu sendiri terbentuk dari beberapa faktor yaitu atribut, nilai, manfaat, budaya, kepribadian dan pemakai (Kotler, 2016). Semakin baik citra merek yang melekat pada produk maka konsumen akan semakin tertarik untuk membeli produk, terutama citra merek pada produk sari roti tersebut.

\section{Kesimpulan}

Berdasarkan hasil penelitian dapat dibuat kesimpulan sebagai berikut :

1. Terdapat pengaruh yang positif dan signifikan antara Persepsi Harga terhadap Keputusan Pembelian, hal ini dibuktikan dalam analisis statistik dimana t-hitung 3,267 > t tabel 1,979 atau sig t $0,001 \leq 0,05$, dengan demikian $\mathrm{H} 1$ diterima

2. Terdapat pengaruh yang positif dan signifikan antara Kualitas Produk terhadap Keputusan Pembelian, hal ini dibuktikan dalam analisis statistik dimana t-hitung 4,262 > t tabel 1,979 atau sig t $0,000 \leq 0,05$, dengan demikian $\mathrm{H} 2$ diterima

3. Terdapat pengaruh yang positif dan signifikan antara Citra Merek terhadap Keputusan Pembelian, hal ini dibuktikan dalam analisis statistik dimana t-hitung 3,176 > t tabel 1,979 atau sig t $0,002 \leq 0,05$, dengan demikian $\mathrm{H} 3$ diterima.

4. Secara simultan terdapat pengaruh yang positif dan signifikan antara Persepsi Harga, Kualitas Produk dan Citra Merek terhadap Keputusan Pembelian, hal ini dibuktikan dalam analisis

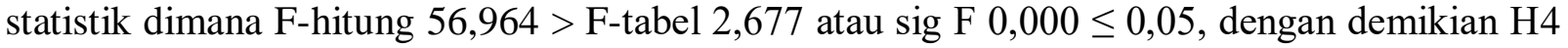
diterima.

\section{Saran}

Berdasarkan kesimpulan yang diperoleh dalam penelitian dapat disampaikan saran sebagai berikut:

1. Produsen Sari Roti harus meningkatkan kualitas secara keseluruhan seperti bermacam-macam varian misalnya dengan menambahkan varian rasa seperti red velvet, green tea dsb dengan tujuan untuk menarik perhatian konsumen dan menjangkau segmen pasarkonsumen yang belum terlayani. Salah satu caranya yaitu dengan menambahkan variasi produk-produkroti khas Eropa dan produk-produk roti sehat yang berbahan dasar gandum.

2. Produsen Sari Roti bisa memperhatikan harga agar tetap bisa sesuai dengan kualitas serta manfaatnya bagi konsumen. Selain itu Sari Roti dapat menciptakan produk-produk baru dengan kualitas yang lebih tinggi dengan tujuan untuk menghadapi pesaing dan memenuhi permintaan pasar yang ada. 
3. Perusahaan Sari Roti dapat memperbaiki dan membangun citra merek yang bagus bagi konsumen, dengan cara menginovasi, memperbaiki dan memproduksi produk Sari Roti sebaik mungkin

4. Bagi peneliti selanjutnya diharapkan semakin memperluas penelitian yang serupa pada tempat atau lokasi yang berbeda dengan menambahkan variabel - variabel lain. Selain menggunakan kuisioner, bisa juga dikembangkan dengan tehnik survey lapangan atau wawancara untuk mengamati kondisi di sekitarnya, sehingga data yang diperoleh lebih lengkap dan dapat mengurangi data yang bersifat subyektif

\section{Daftar Pustaka}

Al Ghozali, Habib Husien Baharudin dan Purwanto, Agus Budi, 2019, Green Product, Saluran Distribusi, dan Brand Image terhadap Keputusan Pembelian, Jurnal Bisnis dan Ekonomi, Vol. 26, (1).

Alma, Buchari, 2016, Manajemen Pemasaran dan Pemasaran Jasa, Alfabeta, Bandung

Arikunto, Suharsimi, 2016, Prosedur Penelitian Suatu Pendekatan Praktik, Rineka Cipta, Jakarta.

Cahya, 2018, Pengaruh Persepsi Harga, Kualitas Produk, Citra Merek dan Layanan Purna Jual Terhadap Keputusan Pembelian dan Dampaknya Terhadap Kepuasan Pelanggan Smartphone Asus Studi Kasus Di PT. DATA SCRIP, Journal of Entrepreneurship, Management, and Industry (JEMI) Vol. 1, No. 01 Maret 2018.

Fernando, Made Fajar dan Aksari, Ni Made Asti, 2018, Pengaruh Kualitas Produk, Harga, Promosi Dan Distribusi Terhadap Keputusan Pembelian Produk Sanitary Ware Toto di Kota Denpasar, E-Jurnal Manajemen Unud, Vol. 7, No. 1, 2018

Ghozali, Imam, 2015, Aplikasi Analisis Multivariate Dengan Program SPSS, Badan Penerbit Universitas Diponegoro, Semarang.

Goetdch dan Davis, 2012, Manajemen Mutu Total, Alih Bahasa; Benjamin Molan, Penyunting Wandansari Mardiarti, PT. Prenhallindo, Jakarta

Indriantoro, Nur dan Bambang Supomo, 2014, Metode Penelitian Bisnis Akuntansi dan Manajemen. BPFE, Yogyakarta.

Kotler, Philip, 2016, Manajemen Pemasaran (Terjemahan), Prenhallindo, Jakarta.

Kotler, Philip dan Amstrong, Gary, 2016, Prinsip-prinsip Pemasaran, Erlangga, Jakarta

Kotler, Philip dan Keller, 2016, Manajemen Pemasaran, Erlangga, Jakarta.

Khakim, Muhammad Luthfi, 2015, Pengaruh Harga, Citra Merek, Kualitas Produk, Dan Kualitas Produk Terhadap Keputusan Pembelian Iphone di Kelurahan Wonodri Semarang, Jurnal Manajemen, Fakutas Ekonomi dan Bisnis Universitas Dian Nuswantoro Semarang

Maindoka, Lifia Filia, 2018, Analisis Pengaruh Citra Merek, Harga dan Desain Produk Terhadap Keputusan Pembelian Mobil Nissa Grand Livina Pada PT.Wahana Wirawan Manado, Jurnal EMBA, Vol.6 No.3 Juli 2018,

Moleong, L.J., 2016, Metodologi Penelitian Kualitatif, PT. Remaja Rosdakarya, Bandung.

Peter dan Olson, 2016, Perilaku Konsumen \& Strategi Pemasaran, Salemba Empat, Jakarta.

Rahmawaty, Penny, 2014, Pengaruh Brand Image, Kualitas Produk, Harga terhadap Keputusan Pembelian Konsumen Sari Roti, Jurnal Ilmu Manajemen, Volume 11, Nomor 2, April 2014

Rangkuti, Freddy, 2016, Measuring Customer Satisfaction, Penerbit PT Gramedia Pustaka Utama, Jakarta

Sangadji, Etta Mamang \& Sopiah. 2015, Perilaku Konsumen, Andi, Yogyakarta 
Vol. 2 No. 1 Maret 2021

Sari, Dianita Yunita, Pengaruh Kualitas Produk, Persepsi Harga, Kualitas Produk dan Lokasi Terhadap Proses Keputusan Pembelian Kapur Barus Merek BAGUS (Studi pada konsumen Giant BSB Semarang), Prosiding SENDI_U, Retrieved from https://www.unisbank.ac.id/ojs/index.php/sendi u/article/ view/6050

Sugiyono, 2016, Metodologi Penelitian, Erlangga, Jakarta.

Sunyoto, Danang, 2016. Dasar-dasar manajemen pemasaran. CAPS, Yogyakarta

Supriyadi, 2016, Pengaruh Kualitas Produk dan Brand Image terhadap Keputusan Pembelian (Studi pada Mahasiswa Pengguna Produk Sepatu Merek Converse di Fisip Universitas Merdeka Malang), Jurnal Bisnis dan Manajemen Vol. 3 No.1, Januari 2016

Thamrin, Abdullah dan Francis Tantri. 2016. Manajemen Pemasaran. PT Raja Grafindo Persada, Depok.

Tjiptono, Fandy, 2016, Strategi Pemasaran, Andi Offset, Yogyakarta

Umar, Husein 2015. Riset Pemasaran dan Perilaku Konsumen, PT. Gramedia Pustaka Utama, Jakarta 
Vol. 2 No. 1 Maret 2021

REKAN

Riset Ekonomi. Aleuntansi dan
e-ISSN : 2721-4109

DOI: 10.30812/rekan.v2i1.1120 